\title{
無線認識技術を用いたアユの行動特性実験 一周囲の明るさ変化に対する反応一 RFID TAGGING EXPERIMENT ON THE EFFECT OF DECREASING LIGHT LEVELS ON THE BEHAVIOR OF AYU FISH
}

\author{
山本亮介 1 ・本田晴朗 2 \\ Ryosuke YAMAMOTO and Haruo HONDA \\ 1正会員 工博 （財）電力中央研究所 水域環境領域（†270-1194 千葉県我孫子市我孫子1646） \\ 2非会員 農博 生物環境領域（同上）
}

\begin{abstract}
Automatic passing fish detection system using RFID (Radio Frequency IDentification) technology was developed to provide information on movement and behavior of Ayu fish (plecoglossus altivelis) within a fishway. In this study, movements of Ayu fish were deduced from detection signals of sensing antennas placed at each remote location to be monitored. To accomplish this, a newly application software which help controlling multiple RFID readers, determining fish locations and logging the detection status was developed. Using developed system, the effect of decreasing light levels on the behavior of Ayu fish within the fish tank was examined. It was found from the result that most of Ayu fish ascended or descended the channel response to the change of light levels and their location was associated with water velocity.
\end{abstract}

Key Words : RFID, plecoglossus altivelis, riverine environment, fishway, suitability criteria

\section{1. はじめに}

河川環境の保全では，生息する動植物の保護が重要と なる．特に日本の河川では，アユやヤマメなどの魚類が 保護の対象となる事が多く, 河川の減水区間において, ダムからの放流量を季節別に調整したり，移動を阻害し ないよう魚道を設置する等して，これら魚類への配慮を 行っている事例が多い. 保護対象となる魚類の中でも， アユは清流を代表する魚として親しまれており，また， 内水面漁業や遊漁の対象としても重要な魚種であるため, 地域住民や漁業関係者などの関心は高く，河川環境の保 全を考える上で，特に重要な魚種となっている.

アユの生息・産卵環境の整備・保全を進める上で，重 要となるのがその行動特性の把握である. 瀬・淵の利用 状況や短期的 - 長期的な河川内での移動特性，出水や周 囲の明るさなど物理的環境の変動に対する応答特性，そ して，選好する地点の水理特性等を詳細に把握できれば， 河川環境の整備・保全を考える際に非常に有用なものと なる. アユは川と海を往来する回遊魚であり, 遡上期・ 成長期・降下産卵期と季節によって異なる生活様式を示 すことが知られている，そのため，詳細なアユの行動特 性の把握には，長期間連続的に追跡・調査するための手
法が必要となる．このような技術は，魚道の利用状況の 確認や，近年，適切な河川流量を評価するために活用さ れる事例の多いPHABSIM ${ }^{1)}$ の適性基準モデルの構築にも 資することができ，現在，その早期確立が望まれている. 魚の行動把握に関する試みとしては，ラジオテレメト リー技術を用いた研究が実施されている。これは魚体に 電波発信器を付け，その信号を追跡することにより，河 川内での魚の位置情報を取得しようというものである. これまでは，サケ・マス類のような比較的大型の魚種に 対して適用される例が多かったが，最近ではアユのよう な小型魚に対して適用した報告例もある2). ラジオテレ メトリー技術は，比較的確立された技術である一方，位 置精度が一般的に若干悪いこと，また，判別できる発信 器の数に制限があること，そして，発信器側に電源を必 要とするため, 追跡できる時間が電池容量に依存するこ と等の制約がある.

一方，ラジオテレメトリー技術とは主用途が異なるが， 非接触で情報をやり取りできる技術として，RFID

(Radio Frequency IDentification, 無線周波数認識システ ム）がある.これは，小型のICタグに記録された情報を 非接触で読み書きするシステムであり，タグ自体が小型 で電源が必要でないこと，タグ自体が比較的安価である 
こと等から，製造や流通，サービス分野等，多くの業種 で幅広く導入されている. トレーサビリティ確保のため, 牛などの生きた動物に装着して利用される例も多い.

幅広い分野で利用されているRFIDであるが，養殖場 等において魚を管理するために利用される例はあるもの の，魚の行動特性を把握するために本格的に利用した例 は少ない，そこで，本研究では，アユの行動特性を個別 に長期間自動的に把握する手法の確立を目指して, RFIDを利用した魚類の検知・追跡システムの構築を 行った. そして，自動的にアユの行動を追跡できるとい う本システムの特徵を生かし, 実河川の調査では把握す る事が難しい, 周囲の明るさが徐々に暗くなっていく環 境下でのアユの行動特性を調べるための室内実験を実施 し，アユの日周活動に関する生態把握に資する事とした

\section{RFIDを用いた魚類検知・追跡システム \\ (1) RFIDシステムの構築}

RFIDは，電波を用い非接触でデータキャリアを自動 で認識する技術で，メモリ機能のあるICチップおよび小 型アンテナが埋め込まれたICタグとリーダルライタが無 線で通信し，個々のIDの識別やデータの読み書きを非接 触で行うことができる．RFIDには，複数の周波数帯が 規格化されており，使用寸る電波の周波数帯で通信距離 や耐ノイズ性，使用できるICタグの形状・大きさ等の特 徵が異なる. 本研究では, 指向性が緩い, 水の影響が少 ない，無線基地局の申請手続きが不要で取り扱いが容易， 既に日本に導入されてから20年近い実績のある等の理由 から，低周波（135KHz以下）を使用するRFID製品を使 用することとした。

本研究で構築した魚類検知システムの概要を図-1に示 す. システムの基盤となるリーダ/ライタユニットは, 米TEXAS INSTRUMENTS社製のRFモジュール（RFM007B）とコントロールモジュール（RI-CTL-MB2B）を 組み合わせて使用した．また，ICタグは同社製のガラス 封入型タグ（RI-TRP-RR3P）を用いることとした. 構築 寸る検知システムには，これらに加え，リーダ/ライタ の制御や検知したID情報を収集保存するためのPC用プ ログラムとアンテナが必要となる．特に，魚の移動を追 跡するためには, 複数のアンテナを同時に組み合わせて 使用する必要があり，これは本来のRFIDの使用形態と 異なることから，複数のリーダルライタを同時制御する ためのWindows OS用ソフトウェアを新規に開発した.

これは，複数のリーダラライタの制御の他，検知状況を PCの画面上でリアルタイムに確認・保存し，また，検 知結果を解析してICタグのID別の出現頻度や時系列での アンテナ別の出現状況をグラフで表示することができる 機能も併せ持つ. また，アンテナについても，市販製品 は数種類の特定サイズのみであること，水中での長期使 用が想定されていないことから，本研究では独自に耐水
仕様のカスタムアンテナを製作した．製作したアンテナ は，アンテナ線にポリウレタン銅線を用い，これを耐衝 撃性硬質ポリ塩化ビニル管で覆うことにより防水性を確 保している．作製したアンテナ $(650 \mathrm{~mm} \times 600 \mathrm{~mm})$ の タグ検知性能を確認したところ, その最大検知距離はア ンテナ面から約330mmであった.

\section{（2）アユへのICタグ装着方法}

本研究では，水中での使用を考慮して円筒状のガラス 封入型ICタグ（長さ $23.1 \mathrm{~mm}$ ，直径 $3.85 \mathrm{~mm}$ ，重さ約 $0.6 \mathrm{~g}$ ) を使用した．このICタグのアユ体外および体内一の装着 方法について, 室内水槽においてアユへの装着実験を行 い, 問題点や魚への影響等を調べた.

まず，体外一の装着は，予めタグピンにICタグを熱収 縮チューブで固定しておき，これをタグガンで魚体に装 着する方法を採用した．魚体の取り付け位置は，脊柱線 上（背ビレの前方，背ビレと脂ビレの間）や神経間棘 （体側背ビレ付近），血管間棘（体側慰ビレ付近）へ装 着する方法を試した，その結果，IC夕グ装着の容易さ， 装着によって魚体にできる傷, 游泳能力への影響, タグ の外れにくさの観点から総合的に判断すると, 体側背ビ レ付近の神経間棘が一番問題の少ない装着位置であるこ とがあきらかになった（図-2）。この位置にタグを装着 したアユは，水槽内で訓致後，装着しないアユと同様に 摂餌活動を行い，また，なわばり行動を示すなど，基本 的な游泳能力に影響が無いことを観察により確認した. なお，このタグ付きアユは，室内水槽飼育で 3 ケ月上 問題なく生存した.

一方，これとは別に，アユの腹腔内一挿入する方法に ついても検討を行った.これは，麻酔した魚体の腹側に $7 \mathrm{~mm}$ 程度の切れ込みを入れ，ICタグを腹腔内に挿入し， 傷口を外科手術用瞬間接着剂で塞ぐ方法である. 腹腔内

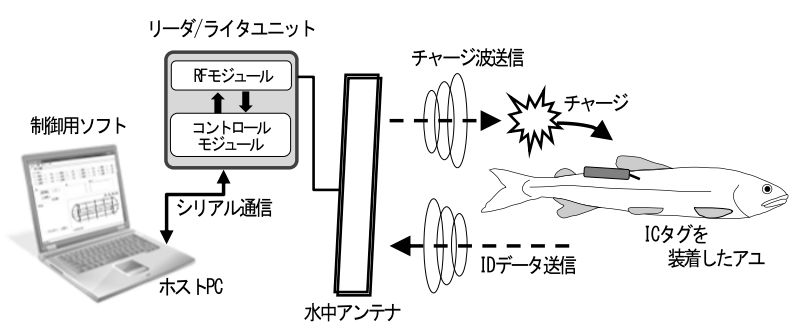

図-1 システムの概要

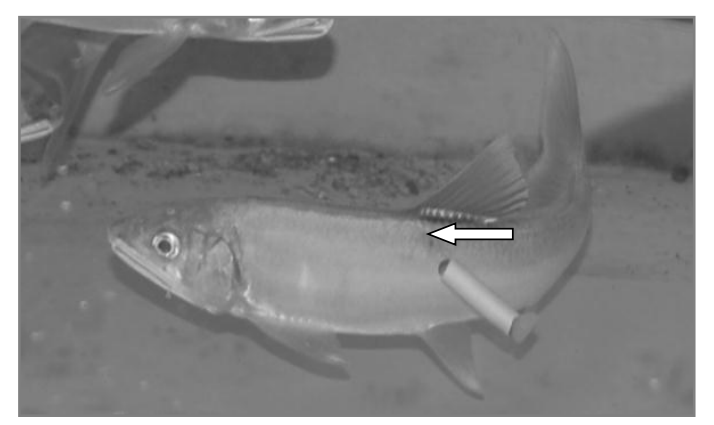

図-2 ICタグの装着位置 
ヘタグを挿入し，術後の予後経過を室内水槽で観察した ところ，施術が成功した個体については，術後3ヶ月以 上の生存を確認した．体内への装着は，若干施術に慣れ が必要なため，体外への装着と比較する万人ができる作 業ではないが，上手く施術できれば，魚体への傷も小さ く, 游泳能力八の影響やタグ脱落が無い, 効果的な方法 であることが確認できた。

\section{3. 周囲の明るさの変化に対するアユの応答実験 \\ （1）実験の概要}

アユは，昼行性の魚で夜間はほとんど活動しない．強 固ななわばりを持った一部のアユを除き，夜間は休息の ため, 流れの緩やかな淵や川岸近くに移動し, 夜明けと ともに流れの速い瀬に出て摂慨活動を開始するとされて いる3),4).アユの日周活動については，このような生態が 一般的に知られているが，夜間暗中での調查や実験が難 しい事から，その行動特性の詳細があきらかにされた例 は少ない. 本研究では, このようなアユの日周活動に関 する生態把握に資するため，構築した魚類検知・追跡シ ステムを用い，周囲の明るさの変化に伴うアユの行動特 性に関する室内実験を実施した.

\section{（2）実験装置}

本室内実験で使用した室内実験装置の概要を図-3に示 す. FRP製回流型水槽 $(8 \mathrm{~m} \times 2 \mathrm{~m}$, 水路幅 $0.6 \mathrm{~m})$ 内にIC タグを検知するためのNo.0からNo.7までのアンテナ（高 さ0.65m，幅0.6m）計8つを図の位置に配置した. そして，

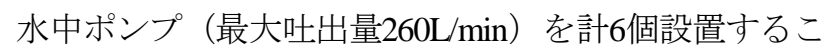
とにより，水槽内に流れを発生させた. ポンプが水中に 設置されており, また, 水槽に曲がり部もあるため, こ れらが流れの抵抗となり, 回流水槽内の流速は一定では なく，流速分布を持つこととなる．また，水槽内の水温 は冷却装置によって制御することが可能となっている. なお，回流水槽内は2枚のステンレス製網によって仕切 られており，アユが進入できない区間が設けられている.

\section{（3）実験条件}

実験中の水槽内の水深は $0.4 \mathrm{~m}$ で一定となるよう調整し,

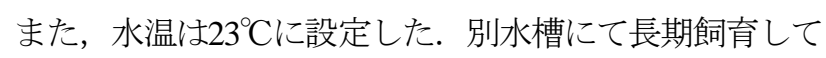
いたアユ13尾（オス7尾，メス6尾，平均全長 $163.7 \mathrm{~mm}$ ) を回流水槽のNo.5アンテナ近傍より放し，5日間の訓致 後に実験を開始した。なお，実験に使用したアユは，千 葉県が生産した人工種苗を手賀沼漁業協同組合が自然日 長下で養殖したものである，また，本実験では，取り付 けの容易さを優先し, 体側背ビレ付近の神経間棘にIC夕 グの装着を行っている.

実験では，室内照明を全灯状態で約5時間保持した後， 完全消灯状態まで一時間近くかけて段階的に消灯してい くことにより, 日没のように水槽周囲の明るさを変化さ せた．検知したタグ情報の記録は消灯開始30分前から実 施し, 完全消灯後3時間30分程度, 計5時間行った. そし て，これを約3日の間隔を空けながら，同条件で計4回繰 り返し行った。実験期間中は，アユは回流水槽に放した ままの状態とし，給慨は毎日一度，実験開始約5 時間前 に行った.

\section{（4）実験結果}

\section{a）回流水槽内流速分布}

回流水槽内の流速分布を測定した結果を図-4に示す. 図は，電磁式流速計を用いて測定された各アンテナ設置 断面および各アンテナ中間地点の平均流速である.

図より，ポンプ群に近いNo.0からNo.2アンテナまでの区 間は流速が速く，特にNo.0アンテナ付近は流速 $0.8 \mathrm{~m} / \mathrm{s}$ 程 度とアユが遊泳するには若干速い流速となっていること， また，No.2からNo.7のアンテナ間は流速約 $0.2 \mathrm{~m} / \mathrm{s}$ 前後で 一定となっていることが確認できる. 本研究では, No.0 からNo.2アンテナまでの区間を“流速の速い区間”，

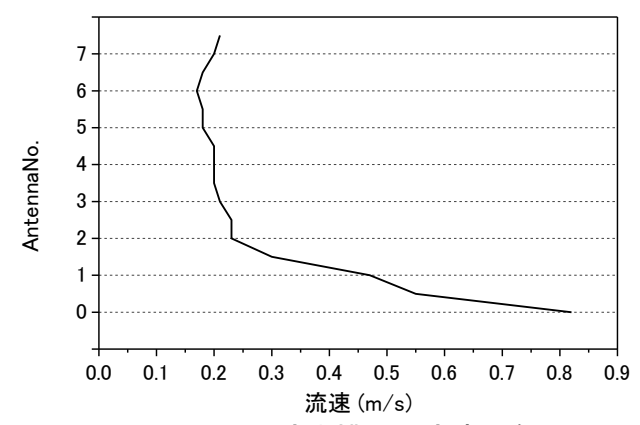

図-4 回流水槽内の流速分布

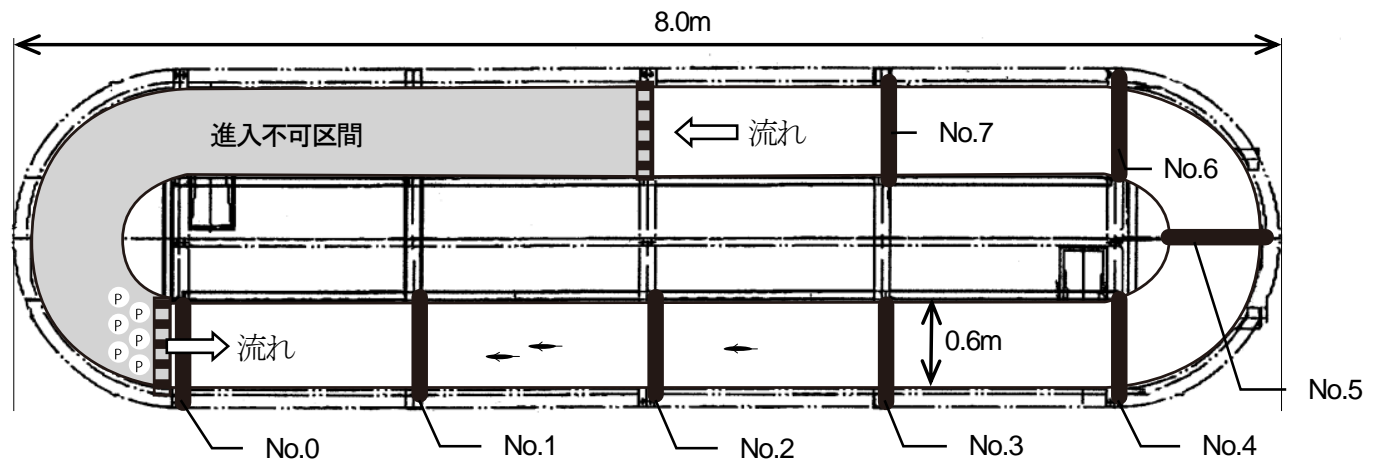

図-3 実験装置の概要 
No.2からNo.7アンテナまでの区間を“流速の遅い区間” と便宜的に呼ぶこととする.

\section{b）周囲が十分明るい環境での選好流速}

全灯時（実験開始後30分間）に記録された個々のアユ が検知された地点（アンテナ番号）の時系列データと前 項で示した各アンテナ設置場所の平均流速から，周囲が 明るい場合にアユが選好している流速を調べた．個々の アユが検知された地点の記録から，そのアユが全灯中に 主に定位していた地点を特定し，その頻度をまとめた結 果を図-5に示寸，図より，周囲が明るい場合には，主に No.1アンテナとNo.2アンテナの各設置地点近辺で定位し ており，その割合は7割弱（図中N1とN12，N2の合計） にあたることがわかる.

著者らは，過去に室内実験により，成長期と産卵期に おけるアユの選好流速を調心゙，アユの選好流速がアユの 体長と比例関係にあることをあきらかにしている5)。こ の既往の試験で得られた成長期のアユの選好流速 $\mathrm{y}(\mathrm{cm} / \mathrm{s})$ と体長 $\mathrm{x}(\mathrm{cm})$ の関係式は次式で表される.

$$
y=5.403 x-44.846
$$

今回の実験より得られた個々のアユの全長とその主な 定位地点の平均流速の関係を図-6に示寸. 図より, 今回 実験に使用したアユの約7割が上記(1)式から得られる選 好流速 $\pm 0.1 \mathrm{~m} / \mathrm{s}$ の範囲の流速を定位位置としていたこと が確認できる.

\section{c）明るさの変化に伴うアユの行動}

構築した検知システムを用いて，明るさの変化に伴う 個々のアユの回流水槽内の行動を追跡した，その結果を

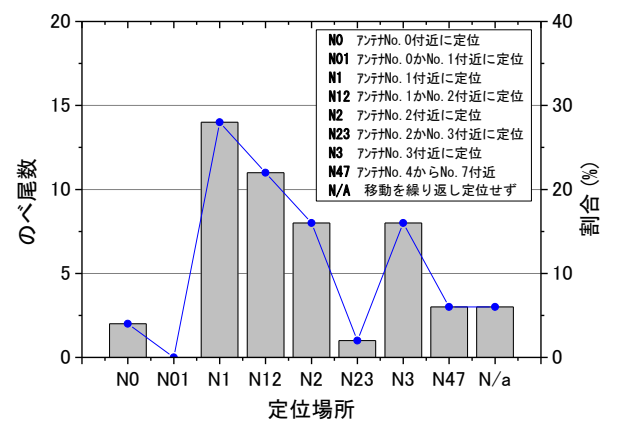

図-5 周囲が明るい場合の選好位置

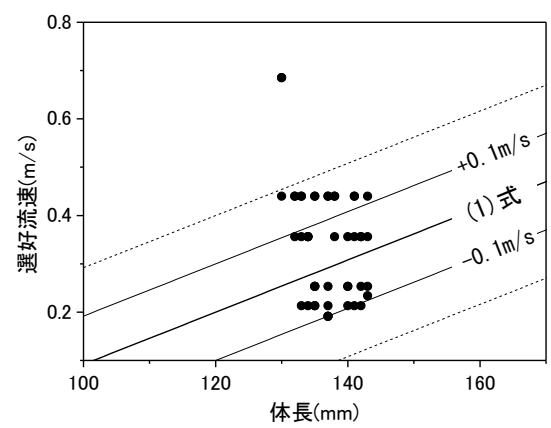

図-6 アュの体長と選好流速の関係
整理するため, ここでは，実験中のアユの行動をまず二 つの様式に分類することとした，すなわち，明るさの変 化にあきらかに無反応であった “A: 行動に変化無し” と “B: 消灯開始後, もしくは完全消灯後の行動が変化” の行動様式である。 また，それぞれの行動様式において も，検出位置の流速に注目してさらに詳細に行動様式の 分類を行った. 分類に用いた詳細な行動様式を表-1に示 す.ここで，表中の速い区間とは，前述のとおりNo.0か らNo.2アンテナまでの区間，遅い区間とはNo.2からNo.7 アンテナまでの区間を指している，なお，分類b1にある “速い区間から更に速い区間へ移動し定位”とは，No.0 からNo.2アンテナの区間の速い流速場中で，No.1地点か らNo.0地点のように明らかに更に速い地点へ移動し定位 した行動様式を意味している.

この表に整理した行動様式に基づき，計4回実施した 実験で得られた個々のアユの行動の記録を解析し，全て のアユの行動について分類を行った. 実験で記録された 行動様式のうち, 典型的な例を図-7 (a) 〜 (e) に示寸. 図 は，それぞれ，a0，a1，b0，b3，b5に分類されたアユの 行動記録であり，対象のアユが実験中に検知された場所 (アンテナ番号) である.

記録開始後30分までは全灯状態で周囲が明るい状態 （照度161lux），30分から1時間15分までの間は，段階 的に消灯し除々に暗くなっている状態（照度136lux $\rightarrow$ 45lux $\rightarrow 14$ lux），1時間15分後以降は完全に消灯した暗中 でのアユの行動で記録ある.これらの図より，同一条件 での実験中であっても，個々のアユによって周囲の明る さへの反応や定位する位置が大きく異なることが確認で きる.なお，照明が全灯状態の記録は最初の30分間しか ないが，実際には実験開始4時間程度前から全灯状態を 保持している.

表-2に実験中の全てのアユの詳細な行動様式の分類結 果を示すこここで，表における性別的はオス，fはメスを 表している. また，この結果を基に，周囲の明るさ変化 に反応した個体，無反応だった個体のそれぞれの割合を

\section{表-1 行動の分類}

\begin{tabular}{|c|c|c|}
\hline 明るさの変化への反応 & 分類 & 行動の詳細 \\
\hline \multirow{3}{*}{ A: 行動に変化無し } & $\mathrm{a} 0$ & 終始速い区間に定位 \\
\hline & a1 & 終始遅い区間に定位 \\
\hline & a2 & $\begin{array}{l}\text { 速い区間·遅い区間の移動を繰り } \\
\text { 返す }\end{array}$ \\
\hline \multirow{6}{*}{$\begin{array}{l}\text { B: 消灯開始後, もしくは完 } \\
\text { 全消灯後の行動が変化 }\end{array}$} & b0 & $\begin{array}{l}\text { 速い区間から遅い区間に移動し } \\
\text { 定位 }\end{array}$ \\
\hline & b1 & $\begin{array}{l}\text { 速い区間から更に速い区間へ移 } \\
\text { 動し定位 }\end{array}$ \\
\hline & b2 & $\begin{array}{l}\text { 遅い区間から速い区間に移動し } \\
\text { 定位 }\end{array}$ \\
\hline & b3 & $\begin{array}{l}\text { 速い区間に定位から 速い区間· } \\
\text { 遅い区間の移動を繰り返す }\end{array}$ \\
\hline & b4 & $\begin{array}{l}\text { 遅い区間に定位から 速い区間· } \\
\text { 遅い区間の移動を繰り返す }\end{array}$ \\
\hline & b5 & $\begin{array}{l}\text { 速い区間·遅い区間の移動を繰り } \\
\text { 返すから 速い区間に定位 }\end{array}$ \\
\hline
\end{tabular}


図-8 (a)に，また，明るさの変化に無反応であった個体 群の詳細な行動パターンの各割合を図-8(b)に，さらに， 明るさの変化に反応した個体群の詳細な行動パターンの
各割合を図-8 (c) に示す．なお，実験4回目のタグNo.6と No.8のアユについては，途中ICタグが脱落し，データに 不備があったため, 分類を行っていない.
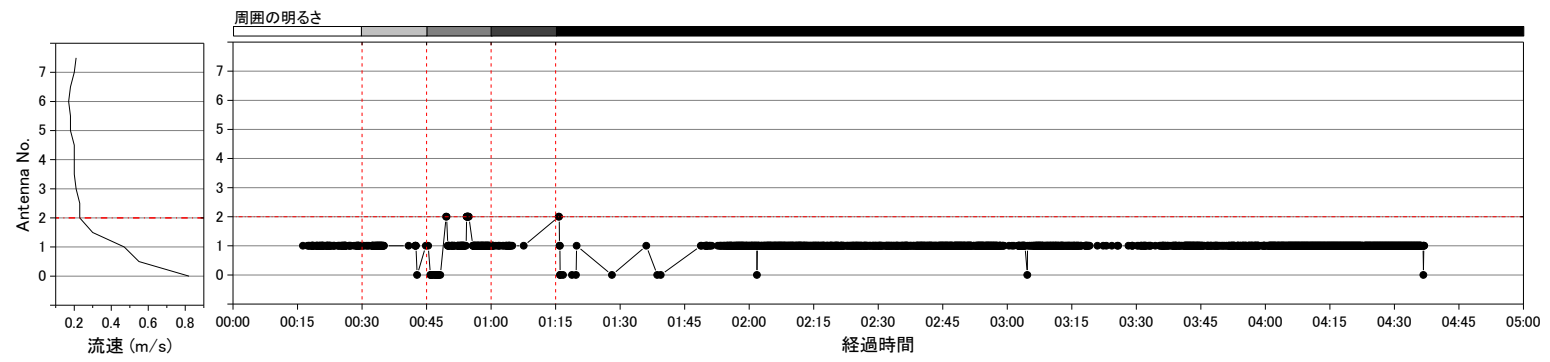

（a）終始速い区間に定位(分類a0)
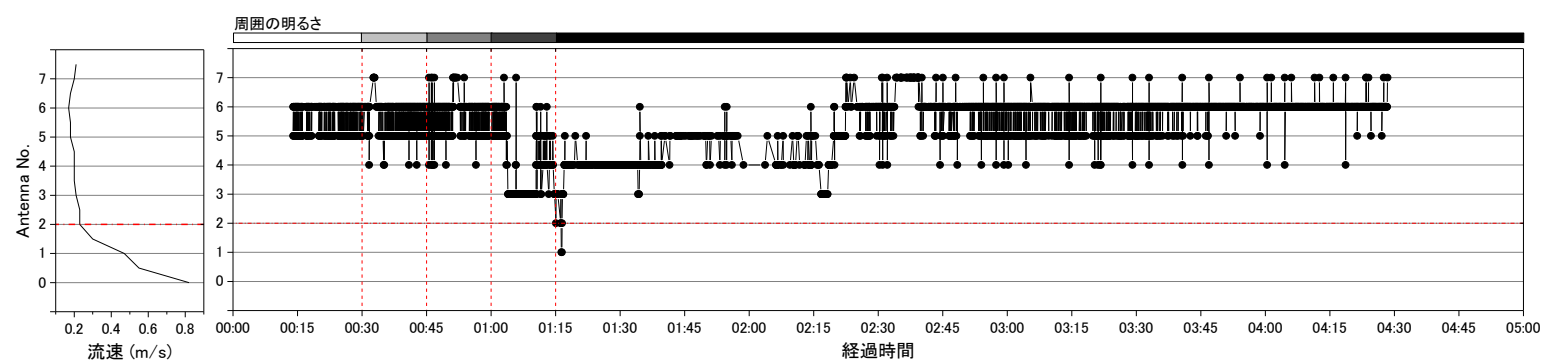

（b）終始遅い区間に定位(分類a1)
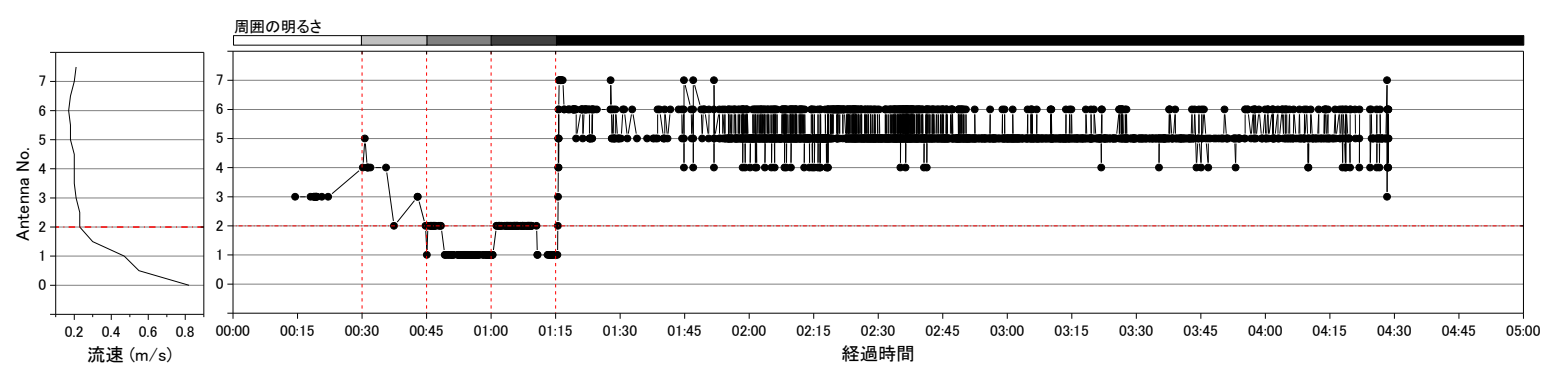

（c）速い区間から遅い区間に移動して定位（分類b0）
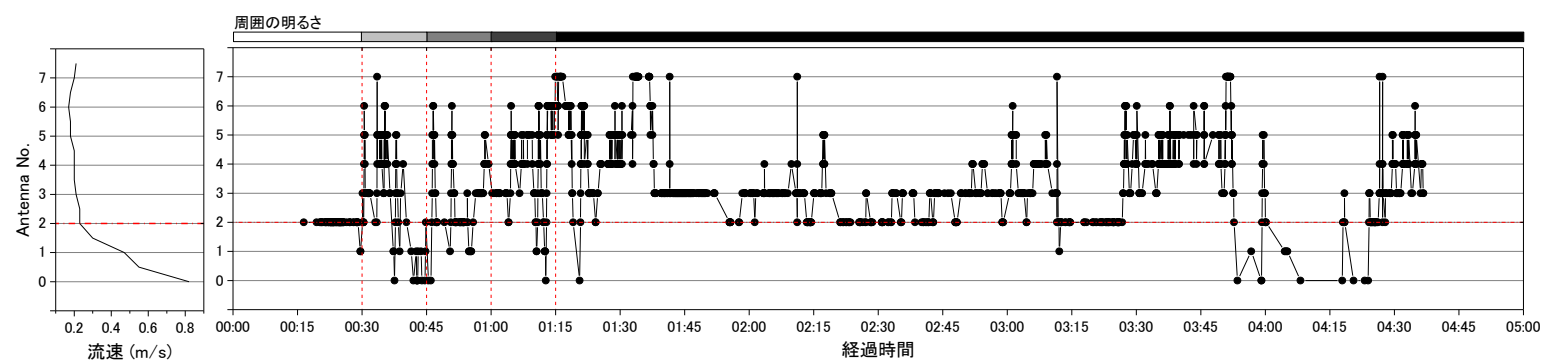

（d）速い区間に定位 から 速い区間・遅い区間の移動を繰り返す(分類b3)
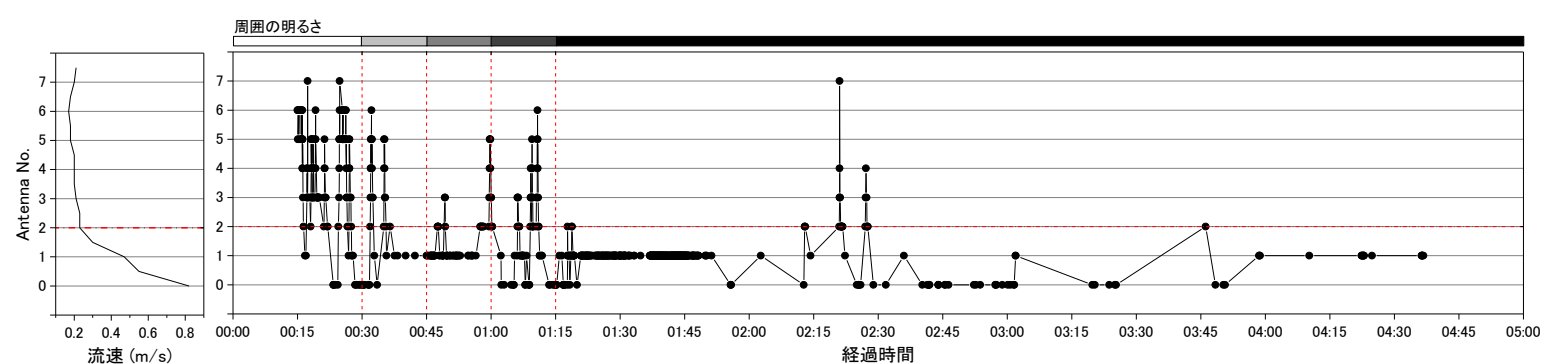

(e) 速い区間・遅い区間の移動を繰り返す から 速い区間に定位(分類b5)

図-7 典型的な行動様式 
表-2 個々のアユの行動様式分類結果

\begin{tabular}{|c|c|c||c|c|c|c|}
\hline タグNo. & 体長(mm) & 性別 & 1回目 & 2回目 & 3回目 & 4回目 \\
\hline \hline 1 & 135 & $\mathrm{~m}$ & $\mathrm{~b} 3$ & $\mathrm{~b} 4$ & $\mathrm{~b} 1$ & $\mathrm{~b} 3$ \\
\hline 2 & 137 & $\mathrm{f}$ & $\mathrm{b} 3$ & $\mathrm{~b} 4$ & $\mathrm{~b} 4$ & $\mathrm{a} 1$ \\
\hline 3 & 130 & $\mathrm{~m}$ & $\mathrm{~b} 5$ & $\mathrm{~b} 3$ & $\mathrm{a} 0$ & $\mathrm{~b} 3$ \\
\hline 4 & 143 & $\mathrm{~m}$ & $\mathrm{a} 0$ & $\mathrm{a} 0$ & $\mathrm{~b} 1$ & $\mathrm{~b} 0$ \\
\hline 5 & 134 & $\mathrm{f}$ & $\mathrm{a} 0$ & $\mathrm{a} 0$ & $\mathrm{~b} 5$ & $\mathrm{~b} 0$ \\
\hline 6 & 132 & $\mathrm{f}$ & $\mathrm{a} 0$ & $\mathrm{a} 0$ & $\mathrm{a} 0$ & - \\
\hline 7 & 142 & $\mathrm{~m}$ & $\mathrm{a} 0$ & $\mathrm{~b} 1$ & $\mathrm{~b} 1$ & $\mathrm{~b} 2$ \\
\hline 8 & 138 & $\mathrm{~m}$ & $\mathrm{a} 0$ & $\mathrm{~b} 1$ & $\mathrm{a} 0$ & - \\
\hline 9 & 140 & $\mathrm{~m}$ & $\mathrm{~b} 0$ & $\mathrm{~b} 0$ & $\mathrm{~b} 0$ & $\mathrm{~b} 0$ \\
\hline 10 & 133 & $\mathrm{f}$ & $\mathrm{b} 1$ & $\mathrm{~b} 1$ & $\mathrm{~b} 1$ & $\mathrm{~b} 2$ \\
\hline 11 & 135 & $\mathrm{~m}$ & $\mathrm{~b} 1$ & $\mathrm{a} 0$ & $\mathrm{a} 0$ & $\mathrm{~b} 0$ \\
\hline 12 & 141 & $\mathrm{f}$ & $\mathrm{b} 0$ & $\mathrm{~b} 0$ & $\mathrm{~b} 0$ & $\mathrm{~b} 0$ \\
\hline 13 & 137 & $\mathrm{f}$ & $\mathrm{b} 0$ & $\mathrm{~b} 0$ & $\mathrm{~b} 0$ & $\mathrm{~b} 4$ \\
\hline
\end{tabular}

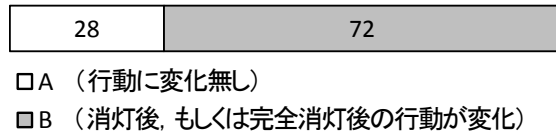

(a) 行動様式AとBの割合 (\%)

\section{\begin{tabular}{|l|l|}
\hline 92.9 & 7.1 \\
\hline
\end{tabular} \\ 口a0（終始速い区間に二定位） ロ a1（終始遅い区間に定位）} (b) 行動様式Aの詳細割合 $(\%)$

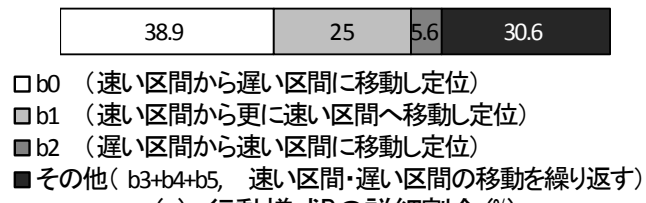

(c) 行動様式Bの詳細割合 $(\%)$

\section{図-8 各行動様式の割合}

まず，表-2より，周囲の明るさ変化に対し行動に変化 があった個体・無かった個体は，アユの大きさや性別に 関係なくそれぞれ一定数存在しており，大きさ・性別の 違いが実験中の行動様式に影響を及ぼしている可能性は 低いことが確認できる.

次に，個々のアユの詳細な行動様式について着目する と，1回目の実験から4回目の実験を通じ，どの個体も最 低2回は同じ行動様式をとっており，その中には全ての 実験で全く同じ行動様式をとる個体が存在することも確 認できる.このことから，その行動内容は異なるものの， 各個体は周囲の明るさ変化に対し，同じような反応を示 す傾向にあることが示唆される.

図-8 (a)に示すとおり，周囲の明るさ変化に対して無 反応で行動に変化がなかった個体の割合は3割弱, 逆に 何らかの反応を示した個体は7割強に上った.この結果 は，一般的に知られているように，アユは日中と日没後 で活動内容が異なることを示唆する結果となっている. そして，図-8(b)に示すとおり，周囲の明るさ変化に対 し無反応であった個体群のうち，実験中終始速い区間に 定位していた個体の割合は9割強であり，残り1割弱が終 始遅い区間に定位していた。その一方，無反応であった
個体群には，速い区間から遅い区間まで頻繁に移動を繰 り返す個体（分類a） は存在しなかった。このことから， 流速が大さく異なる場へ移動する行動は, 周囲の明るさ の変化に反応した結果の行動である可能性が示唆される.

周囲の明るさの変化に反応した個体群については，そ のうち明るさの変化後に速い区間から遅い区間へ移動し た個体の割合は約4割であった。また，遅い区間から速 い区間に移動した個体の割合は，速い区間から更に速い 区間へ移動した個体（b1）の数も含めると約3割，その 他，速い区間・遅い区間の移動を伴う行動をとった個体 が約3割となった（図-8(c)）。アユの特性として，日没 後は流れの緩やかな場所に移動し休息を行うことが知ら れていることから，実験では行動様式b0をとる個体が多 くなると予想していた。 そして，その予想どおりb0の行 動様式をとる個体が一番多い結果となったが，流れの速 い場所に移動した個体も少なからず存在する結果となっ ている. 本実験水槽は, 最も流速の速いアンテナNo.0付 近より上流側へは流れを遡って移動できない構造となっ ており，遅い区間から速い区間へ移動した個体が，流れ の速い場所を選好したのではなく，流れの緩やかな場所 を探して上流へと移動する過程で行く手を遮られ，流れ の速い場所に留まっていた可能性もある.この点につい ては，今後更なる確認が必要である。

\section{5. おわりに}

本研究では，RFIDを利用した魚類の位置検知・追跡 システムの構築を行い，これを室内実験に適用した．実 験では，日没のように周囲の明るさが変化する中での 個々のアユの行動を追跡し，得られた時系列データを基 に，明るさの変化に伴うアユの定位場所の変化等に関し て分析と考察を行った. 今後は, 構築したシステムを用 いて, 流量 (流速) の変動に対するアユの行動特性や, アユやヤマメ等, 河川保全上重要となる魚類の水理物理 量に関する選好特性をあきらかにするため, 本システム を用いた室内実験や現場試験を行う予定である.

\section{参考文献}

1) Stalnaker, c. et al. : The Instream Flow Incremental Methodology A Primer for IFIM, Biological Report 29, U.S. Department of the Interior,National Biological Service, 1995.

2) 䋶纐渉 ほか: 野生動物自動行動追跡システムを用いた降下 期のアユ行動特性の把握, 応用生態工学会第14回研究発表会 講演集, pp.203-206, 2010.

3) 宮地伝三郎 : アユの話, 岩波書店, 1994.

4) 小山長雄 : アユの生態, 中公新書, 1978.

5) 本田晴朗・山本亮介 : 成長期および産卵期における人工種苗 アユの選好流速, 水産増殖, 54(4),pp.421-427, 2006.

(2011. 9. 30受付) 